\title{
Pregled razvoja odgoja i obrazovanja za vrijednosti u okvirima povijesno-društvenoga konteksta
}

\author{
Vjera Brković*, Rona Bušljeta Kardum**
}

\begin{abstract}
Sažetak
Odgoj i obrazovanje za vrijednosti omogućavaju bitnost postojanja te se često promatraju kao neizostavni razvojni društveni fenomen koji opstaje unatoč povijesnim mijenama. Ipak potrebno je naglasiti da povijesno-društveni kontekst $u$ skladu s vremenom oblikuje svoj sustav vrijednosti koje novi naraštaji prihvaćaju ili odbacuju. S obzirom na važnost odgoja i obrazovanja za vrijednosti u formiranju čovjeka i razvoja društva, ovim se radom imalo za cilj detektirati ishodišta univerzalnih odgojno-obrazovnih vrijednosti, rekonstruirati povijesno-društveni kontekst nastanka te pratiti kontinuitet i promjene procesa razvoja odgoja i obrazovanja za vrijednosti. Izdvojeni su primjeri univerzalnih odgojno-obrazovnih vrijednosti koje nam je ostavila u nasljede povijest, a to su: mudrost, odnosno razboritost, hrabrost, umjerenost, pravednost, požrtvovnost, skromnost, duhovnost, briga za roditelje i starije, ljubav prema domovini, dobrota, sloboda, pravda, mir, dostojanstvo, demokracija, jednakost, vladavina prava, ljudska prava, uključivost, tolerancija, solidarnost i nediskriminacija.
\end{abstract}

Ključne riječi: aksiologija; odgoj i obrazovanje; povijesno-društveni kontekst; univerzalne vrijednosti

\section{Uvod}

U nas je vrlo malo toga napisano o odgoju i obrazovanju za vrijednosti, a još se manje pronalaze cjeloviti radovi koji daju pregled kontinuiteta i promjena odgoja i obrazovanja za vrijednosti kroz povijest. Polazište proučavanju odgoja

* Vjera Brković, predavač, doktorand, Hrvatsko katoličko sveučilište, Odjel za povijest, Ilica 242, 10000 Zagreb, Hrvatska. ORCID iD: https://orcid.org/0000-0001-9025-2540.

E-adresa:vjera.brkovic@unicath.hr

** Doc. dr. sc. Rona Bušljeta Kardum, Fakultet hrvatskih studija, Sveučilište u Zagrebu, Borongajska cesta 83d, 10000 Zagreb, Hrvatska. ORCID iD: https://orcid.org/0000-0002-7158-0044. E-adresa: rbusljeta@hrstud.hr 
i obrazovanja za vrijednosti treba tražiti u filozofiji, točnije u antičkoj filozofiji, koja određuje čovjeka kao društveno biće, odnosno kao zoon politikon (Aristotel, 1988, 21-22), ${ }^{1}$ naglašavajući time da je čovjek biće zajednice, u kojoj barem do neke mjere moraju biti usklađene vrijednosti i norme. Iz filozofske misli poteklo je ne samo filozofsko mišljenje o odgoju, nego i kulturno-civilizacijski identitet - misao zapadnoga svijeta uopće, kao i vrijednosna slika svijeta, što je utkano i u razvoj odgoja i obrazovanja (Kokić, 2015, 45). Tako je antička filozofija oblikovala mišljenje koje je s kasnijim razvojem pedagogijske aksiologije poduprlo opći znanstveni interes za izravnim proučavanjem vrijednosti i vrijednosnih sustava (Mrnjaus, 2007, 59).

Čovjeka istovremeno određuje društvo, ali je i određen društvom. On na razne načine sudjeluje u društvenim procesima i usvaja različite kulturne i društvene obrasce konstruirajući svoja individualna znanja i značenja, a odgoj se u tome kontekstu promatra kao fenomen koji utječe na sveobuhvatnu izgradnju čovjeka kao društvenoga bića (Vukasović, 2013, 256).

Tema odgoja i obrazovanja za vrijednosti vrlo je kompleksna jer obuhvaća ne samo potrebu za interdisciplinarnim pristupom, nego zahtijeva i cjelovito razumijevanje povijesno-društvenoga konteksta koji utječe na promjene odgojnoobrazovnih vrijednosti. Pođemo li od toga da se vrijednosti mogu definirati kao plod interakcije individualnih, socijalnih i povijesnih čimbenika, jasno je da je odgoj i obrazovanje za vrijednosti donekle uvjetovan i vezan uz povijesne mijene.

\section{Ishodište odgojno-obrazovnih vrijednosti - Antički odgojni ideal}

Odgoj i obrazovanje od najranijih vremena do danas omogućavaju oblikovanje pojedinca, a tijekom povijesti odgoj i obrazovanje utječu na razvoj ljudske zajednice. Pokušaj preciznijega određivanja vremena kada se je pojavila potreba za prenošenjem vrijednosti može odvesti u najranije prapovijesno doba i vrijeme oblikovanja prvih društvenih zajednica, o čemu svjedoče prapovijesni ostatci. Međutim, odgajanje i obrazovanje za vrijednosti ipak se jasnije može pratiti u starom vijeku, i to na primjeru antičke Grčke, koja se smatra kolijevkom europske civilizacije u svakom pogledu, pa tako i u pogledu razvoja odgojno-obrazovnih vrijednosti (Krasić, 2012, 19). Primjer cjelovitoga odgoja u starom vijeku atenski je odgojni ideal definiran terminom kalokagatija (ljepota i dobrota) (Senković, 2006, 44). Cilj je takvoga odgoja kalokagatos, čovjek lijepoga, snažno građenoga tijela i visokoga morala (Pranjić, 2013, 68-74). Ipak, ključne ideje o odgoju i odgojnim vrijednostima nalaze se u djelima antičkih filozofa, kao što su Protagora, Sokrat, Platon, Aristotel, Ciceron, Kvintilijan i dr. ${ }^{2}$

1 Aristotel na prvim stranicama Politike određuje čovjeka kao zoon politikon, tj. kao biće određeno vlastitom društvenošću.

2 U literaturi se mogu pronaći različiti termini za vrijednosti, poput vrlina (grč. arete) ili krjeposti. Aristotel u svome djelu Nikomahova etika zastupa tzv. etiku vrlina, u kojoj vrline dijeli na intelektualne i moralne. Intelektualne su vezane za učenje, a etičke su stvar običaja, ćudoređa, normi 
$\mathrm{U}$ antici su se profilirale četiri temeljne vrijednosti koje su postale univerzalne: mudrost, hrabrost, umjerenost i pravednost. Osim navedenih univerzalnih vrijednosti antička društva, naime, ističu još neke poželjne vrijednosti za izgradnju pojedinca i društva: požrtvovnost, pokoravanje bogovima, roditeljima i starijima, skromnost i ljubav prema domovini (Kale, 1990, 58-66). U kasnijim razdobljima ne možemo govoriti o nestanku antičkih vrijednosti, nego o tome da se one proširuju i nadograđuju, ovisno o povijesno-društvenim zbivanjima i događajima.

\subsection{Nasljedovanje antičkih vrijednosti - Srednji vijek}

Često neopravdane konstrukcije prema kojima je »srednji vijek mračno razdoblje « mogu se dovesti u pitanje. Srednji vijek kao nijedno drugo povijesno razdoblje nije samo po sebi ni "mračno" ni "svijetlo". Francuski stručnjak za srenjovjekovlje Le Goff proučavao je povijest ideja i mentaliteta te različite razvojne komponente kulture srednjega vijeka. On ističe da na srednji vijek ne treba gledati kao na razdoblje mraka, štoviše, u nekim slučajevima može ga se smatrati i kao seculum modernum, odnosno modernim dobom (Le Goff, 2011, 89). Negativne konstrukcije nisu opravdane imamo li u vidu i kontekst razvoja kulture i znanstvenih ustanova (sveučilišta) u srednjem vijeku (Krasić, 2012, 13). Ljudsko stvaralaštvo i vrijednosti toga vremena prisutne su u duhovnoj i kulturnoj ostavštini umjetničkih pravaca romanike i gotike, ali i u znanstvenim oazama toga vremena - prvim europskim sveučilištima (Bologna, Sorbona, Oxford, Cambridge, Padova i dr.) (Krasić, 2012, 13-14). Dakle, ne bi bilo pogrešno tvrditi kako je razdoblje srednjega vijeka ostavilo neizbrisiv trag, danas vidljiv dio povijesnokulturnoga nasljeđa europskoga civilizacijsko-kulturnoga kruga.

Društvene promjene srednjega vijeka mogu se kronološki prikazati u razvoju školstva. Tako se srednjovjekovni odgoj i obrazovanje dijeli na razdoblje velikoga utjecaja Crkve i postojanja crkvenih škola od 5. do 12. stoljeća (Krasić, 2012, 195-199) i na razdoblje od 12. do 14. stoljeća, kada je bio prisutan i tzv. "viteški odgoj”, utemeljen na sedam viteških vještina, septem artes probitatis (Bognar i Svalina, 2013, 230). ${ }^{3}$

U srednjem vijeku primjetno je kako su se antički odgojni ideali promicali i nastavljali razvijati. Kršćanstvo nasljeđuje antičke vrijednosti, koje su usvojene kao »temeljne kršćanske kreposti« — razboritost, jakost, umjerenost i pravednost te tako postaju vrijednosti koje su nadišle sve povijesne mijene i ostale prisutne do danas (CCE). Bitan utjecaj na odgoj čovjeka u srednjemu vijeku, u svakom pogledu, imao je nauk Katoličke crkve (Senković, 2006, 47-51). Utjecaj na odgoj, ali i rekonstrukciju srednjevjekovnih odgojnih vrijednosti, moguće je napraviti prema sedam smrtnih grijeha, te tako izdvojiti suprotnosti koje opisuju

i konvencija koje vladaju u nekom društvu. Etička komponenta može se shvatiti i kao odgojni element — rast u ćudoređu, tj. odgajanje ćudi ili usavršavanje čovjekove naravi.

3 Riječ je o "viteškim umijećima" na kojima je insistirano kod viteškoga odgoja. Umijeća obuhvaćaju jahanje, bacanje koplja, plivanje, mačevanje, lov, igranje dame i skladanje stihova. 
poželjno i nepoželjno i koje su kao takve duboko ukorijenjene u srednjevjekovnu koncepciju odgoja: 1. oholost - poniznost, 2. škrtost — darežljivost, 3. bludnost — čednost, 4. zavist — blagonaklonost, 5. neumjerenost u jelu i piću — suzdržanost, 6. srdžba - praštanje, 7. lijenost - marljivost (Berčić, 2008, 194).

Krajem 13. stoljeća došlo je do društvenih promjena koje zahtijevaju novi koncept odgoja i obrazovanja te se je osjećao jači utjecaj novoga poimanja odgojno-obrazovnih vrijednosti u duhu građanskoga odgoja, koji se je još jasnije definirao u humanizmu i renesansi (Grubiša, 2010, 9-10).

\subsection{Prema novom poimanju odgojno-obrazovnih vrijednosti - homo universalis}

Razdoblje kasne srednjovjekovne povijesti obilježeno je težnjom za upoznavanjem i nasljedovanjem antičke filozofije, uklapanjem u kršćansku srednjovjekovnu filozofiju te vjerom u sposobnost i vrijednost čovjeka. Humanističko-renesansno poimanje odgojno-obrazovnih vrijednosti temelji se na pedagogiji renesanse, koja ističe potrebu razvoja dječje aktivnosti i radoznalosti u otkrivanju novoga te veliku važnost pridaje intelektualnomu razvoju (Arthur, 2020, 89-92). Ideal je humanizma svestran čovjek homo universalis, koji razvija svekolike umne sposobnosti, slobodan duh koji teži preispitivanju uvriježenih uvjerenja, kao i stjecanju novih znanja. Jedan od važnih moralista koji se je zalagao za cjelovit odgoj, u smislu usklađenoga razvoja uma, tijela i moralnosti toga vremena, bio je francuski pisac i filozof Montaigne. ${ }^{4}$

Važne promjene u društvu nastupile su krajem 17. stoljeća, kada se je razvilo prosvjetiteljstvo kao ideološki i obrazovni pokret (Veljak, 2013, 120). Prosvjetiteljstvo je snažno utjecalo na kulturni i pedagoški život 18. i 19. stoljeća, pa je tako došlo i do protivljenja srednjovjekovnim utjecajima i njihova gotovo potpunoga odbacivanja. S razdobljem prosvjetiteljstva otvara se novi pogled na odgojno-obrazovne vrijednosti, na koje je isključivo gledano kao na moralne ideje (Legrand, 1991, 42-44) koje vode spajanju moralnoga, intelektualnoga i duhovnoga života.

\section{Novovjekovlje i suvremeno razdoblje}

\subsection{Prosvjetiteljstvo i klasični njemački idealizam}

Glavna uporišta odgojno-obrazovnih vrijednosti u prosvjetiteljstvu zasnovana su na Baconovu empirizmu i Descartesovu racionalizmu (Veljak, 2013, 120 121). Prosvjetiteljstvo je odbacilo srednjevjekovno obrazovanje i odredilo je tzv. program realnoga obrazovanja, u kojem je naglašena važnost intelektualnoga i

4 Napisao je djelo Ogledi (1580.) o raznim temama od filozofije života, pedagoških i obrazovnih tema, raznih političkih koncepcija do shvaćanja religije. Dao je velik doprinos promicanju odgojnih vrijednosti toga razdoblja s naglaskom na cjeloviti pristup razvoja čovjeka posredstvom odgoja i obrazovanja. 
moralnoga razvoja, kao i važnost utjecaja društvene sredine na razvoj svakoga pojedinca (Vergnioux, 2017, 58-64). Pokušamo li izdvojiti glavna obilježja 18. stoljeća u smislu razvoja pedagoške misli o odgojno-obrazovnim vrijednostima, moramo znati da je odgoj bio obilježen pedagoškim učenjem Lockea o spoznajnoj teoriji (Papo, 2016, 30), ${ }^{5} \mathrm{u}$ čijem je fokusu iskustvo, te učenjem i stajalištima francuskih filozofa koji su razvili materijalističku teoriju morala (La Mettrie, 1955), ${ }^{6}$ ali i učenjem Rousseaua, koji je isticao svoje specifične odgojne ciljeve sa zadaćom »odgojiti čovjeka«. Rousseau polazi od postavke da je čovjek po prirodi dobar te je cilj odgoja odgajanje dobrote (Golubović, 2013, 32-35). ${ }^{7}$

Ideje o odgojno-obrazovnim vrijednostima iz 18. stoljeća nastavile su se razvijati u 19. stoljeću pod snažnim utjecajem njemačkih filozofa, tvoraca tzv. klasičnoga njemačkoga idealizma Kanta, Fichtea, Schellinga i Hegela. Njihova učenja snažno su utjecala na razvoj pedagoške misli o odgojno-obrazovnim vrijednostima, koje se prema njima postižu posredovanjem odgoja i obrazovanja (Hegel, 1976, 139). Pod utjecajem prosvjetiteljstva (Rousseaua) i njemačkoga idealizma (Leibniza, Kanta) važno mjesto među pedagogijskim klasicima zauzima i Pestalozzi. Pastalozzi shvaća odgoj kao nadogradnju prirodnih pozitivnih snaga u djetetu, a svrha mu je svestrano, postupno i harmonično razvijanje tjelesnih, intelektualnih, moralnih i radnih sposobnosti (»uma, srca i ruku«). ${ }^{8}$

\subsection{Devetnaesto stoljeće - ideje o građanskim pravima i građanskim slobodama}

Krajem 18. stoljeća i tijekom 19. stoljeća povijesno-društveni kontekst upućuje na to da se pod utjecajem prosvjetiteljskih ideja i utjecajem pravnih dokumenata koji su proizišli iz američkih zakonskih propisa i tekovina francuske revolucije formira svijest o građanskim pravima i građanskim slobodama (Hobsbawm, 1987, 54-68). ${ }^{9}$ Po uzoru na američku Deklaraciju o neovisnosti iz 1776. godine francuski su revolucionari 1789. godine dokinuli feudalne povlastice i donijeli Deklaraciju o pravima čovjeka i građanina, u kojoj su sloboda, sigurnost, vlasništvo i pravo na otpor proglašeni neotuđivim ljudskim pravima. Tim dokumentima

5 Autor je razložio kritički osvrt velikoga hrvatskog aksiologa i filozofa Pavla Vuk-Pavlovića na najvažnija Lockeova djela.

6 Pozitivno shvaćanje materijalizma, u kontekstu radikalnoga prosvjetiteljstva, među prvima uvodi La Mettrie, kao oznaku vlastitoga metafizičkoga stajališta suprotstavljenoga spiritualizmu. Definicije materijalističke teorije morala mogu se još pronaći i u djelima Diderota, Holbacha i drugih francuskih filozofa.

7 Ideje o odgojnim načelima pojašnjene su u djelu Emil ili o odgoju.

8 Johann Heinrich Pestalozzi, švicarski pedagog, jedan je od najistaknutijih prethodnika moderne znanstvene pedagogije, a važnija su mu djela: Lienhard i Gertruda (I-IV); Kako Gertruda uči svoje dijete; O zamisli osnovnoga odgoja; $O$ odgoju u skladu s prirodom.

9 Navedene revolucije u historiografiji često se spominju kao doba revolucija, a najčešce je omeđeno Francuskom revolucijom i proljećem naroda, odnosno revolucijama 1848.-1849. godine. Doba revolucija pritom je uzeto u širem kontekstu te ne obuhvaća samo revolucionarna zbivanja u vidu ustanaka i nemira, nego i revolucije na području industrije, znanosti, politike i ideologije, pa tako posljedično na području svakodnevice i društva općenito, što utječe i na odgojno-obrazovne koncepcije. 
formiran je svjetonazorski i ideološki okvir gotovo svih reformatorskih i revolucionarnih pokreta u 19. stoljeću. Liberalizam je postao nova ideologija u kojoj su »sloboda i jednakost « postale neupitne vrijednosti kojima tadašnje društvo treba težiti. Utjecaj liberalizma na poimanje odgojno-obrazovnih vrijednosti do danas je od presudne važnosti. U tom se pogledu predlažu ideje prema kojima treba odgajati čovjeka: ideja unutrašnje slobode, ideja savršenstva, ideja dobrote, ideja prava i ideja pravde (Brčić, 2006, 790). Pod utjecajem Kanta i Fichtea djelovao je Herbart, utemeljitelj znanstvene pedagogije u 19. stoljeću. Pedagogija iz perspektive znanosti o odgoju i obrazovanju odgojno-obrazovne vrijednosti proučava u smislu razvoja sposobnosti koje pojedincu omogućavaju upoznavanje ljudskih, materijalnih i duhovnih vrijednosti prema kojima će moći formirati vlastite vrijednosti kojima se povodi (Mijatović, 2000, 283). Herbart u svojim radovima raspravlja o problemima moralnoga odgoja kojima prilazi iz pozicije intelektualizma. Herbartovi odgojno-obrazovni ciljevi odnose se na formiranje moralnoga karaktera, razvijanje aktivnosti i usmjeravanje pojedinca na samoaktualizaciju (Palekčić, 2010, 325-331). Osim što je 19. stoljeće obilježeno velikim imenima, klasicima njemačke filozofije i pedagogije, obilježeno je i novim učenjima socijalnih utopista koja su utjecali na razvoj pedagoške misli 19. i 20. stoljeća. Pod utjecajem Saint-Simona, Fouriera i Owena razvijena je socijalistička pedagogija. Imena Marxa i Engelsa osobito su bila važna za socijalističku pedagogiju. Iako oni nisu pisali posebne pedagoške rasprave, dali su temeljne postavke za odgojne ideale. Socijalističko učenje naglašava da je cilj odgoja razvoj čovjeka umnim i fizičkim odgojem s potrebom spajanja proizvodnoga rada i nastave (Zaninović, 1988, 198). U istom razdoblju, osim socijalističke pedagogije, pod utjecajem duhovne i kulturne krize razvijene su filozofijska i kulturna pedagogija. Ti su pravci snažno utjecali na promicanje općeljudskih vrijednosti. ${ }^{10}$ Najvažniji su predstavnici filozofijske i kulturne pedagogije Dilthey, Spranger i Litt (Palmer, 2007, 52). Oni su zaslužni za teoriju koja uz pomoć odgoja nastoji revitalizirati kulturni život, a temelji se na filozofiji kulture, duhovno-znanstvenoj i strukturnoj psihologiji. Smatraju da je kultura najvažnija u čovjekovu životu i odgoju. Ističu da odgoj mora čuvati i razvijati kulturu, a ona je temelj učinkovitoga odgoja i obrazovanja, čiji je krajnji cilj u pojedinca razvijati smisao za vrijednosti (Palmer, 2007, 53-549).

\subsection{Dvadeseto stoljeće — potreba za očuvanjem i zaštitom općeljudskih vrijednosti}

Praćenje odgoja i obrazovanja za vrijednosti u razdoblju kraja 19. stoljeća i početka 20. stoljeća svakako se može vezati uz Deweyja, filozofa i pedagoga koji

10 Wilhelm Dilthey glavni je začetnik i predstavnik kulturne pedagogije i njezinih posebnih smjerova vrijednosne ili aksiološke pedagogije. Smatrao je da je odgoj u funkciji revitalizacije ljudske kulture, a svrha mu je prihvaćanje kulturnih i općeljudskih vrijednosti posredovanjem duhovnih znanosti. Glavna su njegova djela: Einleitung in die Geisteswissenschaften ("Uvod u duhovne znanosti", 1883.) i Der Aufbau der geschichtlichen Welt in den Geisteswissenschaften ("Izgradnja povijesnoga svijeta u duhovnim znanostima”, 1910.). 
je svoje pedagoške teze izložio u mnogobrojnim radovima. ${ }^{11}$ Raspravljajući o pitanjima odgoja i obrazovanja, Dewey je smatrao da je odgoj »životna potreba« jer bi bez odgoja, tj. bez prenošenja vrijednosti, ljudska vrsta brzo podlegnula stihiji (Dewey, 1953, 43).

Međutim, želimo li steći cjeloviti uvid u razvoj i brigu za očuvanjem vrijednosti krajem 19. i u 20. stoljeću, ipak treba promatrati u širem kontekstu društvenih, kulturnih, pedagoških događaja i zbivanja.

Razdoblje 20. stoljeća obilježeno je različitim krizama i lokalnim ratovima, imperijalizmom, naoružanjem, totalnim ratovima, destrukcijom, totalitarnim režimima, masovnim stradanjima i sl. (Ravlić, 2001, 156-160). ${ }^{12}$ Navedeni događaji izravno su utjecali na potrebu za očuvanjem i zaštitom općeljudskih vrijednosti koje su sadržane u općoj deklaraciji o ljudskim pravima iz 1948. (Ujedinjeni narodi, 2009) i Konvenciji o pravima djeteta iz 1989. (Ujedinjeni narodi, s. a.). Vrijednosti: mir, dostojanstvo, sloboda, demokracija, jednakost, vladavina prava, ljudska prava, uključivost, tolerancija, pravda, solidarnost i nediskriminacija prema navedenim dokumentima univerzalne su vrijednosti koje bi trebale biti zajamčene svim ljudima. ${ }^{13}$

U drugoj polovici 20. stoljeća, u teorijskom i istraživačkom smislu, više nego u ostalim znanostima, jačao je interes psihologije za izravno proučavanje odgoja za vrijednosti i vrijednosnih sustava, kao i težnja za spoznavanjem odgoja i njegova značenja u ljudskom životu i društvu, što se snažno osjeća u dostupnoj literaturi. Od tada do danas, veliku ulogu u otvaranju teme o utjecaju vrijednosti na proces učenja imao je humanistički pristup odgoju i Maslowljeva teorija hijerarhije. Maslow pod vrijednostima podrazumijeva svrhovitost, odnosno razumijevanje cilja koji se želi doseći, te smatra da je dosezanje autonomno postavljenih vrijednosti kontinuirani proces učenja, a osvješćivanje i življenje vrijednosti bitna pretpostavka čovjekove samoaktualizacije (Maslow, 1968, 185).

\subsection{Interpretacije i perspektive u 21. stoljeću - suvremeno poimanje vrijednosti}

Sveobuhvatne promjene društvenoga konteksta događale su se neprimjetno, ali mijenjale su položaj, društvenost, identitet i procese čovjekove samokonstrukcije. Društveni kontekst u 21. stoljeću čine pojmovi: postindustrijsko društvo, umreženo društvo, globalno društvo, društvo koje uči, društvo temeljeno na zna-

11 Najvažnija su Deweyeva djela u kojima promišlja o odgoju Democracy and Education ("Demokracija i obrazovanje"), School and Society ("Škola i društvo"), Reconstruction in Philosophy ("Rekonstrukcija u filozofiji") i School of the Future ("Škola budućnosti").

12 Sve tri ideologije — komunizam, nacizam i fašizam — smatrale su da posjeduju neoborivu istinu o čovjeku, a odgoj i obrazovanje u kontekstu vrijednosti utemeljeni su na ideološkoj osnovi. Političke ideologije motiviraju djelovanje, koje može biti djelovanje na uspostavljanju ili održavanju određenih vrijednosti i vjerovanja, stvaranju socijalnoga pritiska prema postizanju željene društvene promjene.

13 Primjer zajedničkoga nastojanja zaštite temeljnih vrijednosti vidljiv je u ciljevima i sadržaju Ugovora iz Lisabona (2007.), ali i u Povelji Europske unije o temeljnim pravima (2016.). Danas države članice Europske unije dijele sve navedene vrijednosti. 
nju, informatičko društvo i sl. (Kovačević i Mušanović, 2013, 119). Analizirajući vrijednosti i njihov kontinuitet prenošenja sa starijih na mlađe naraštaje od antike, srednjega vijeka, novovjekovnoga razdoblja pa sve do 21. stoljeća, uočljive su promjene, ali i kontinuitet u poimanju pojma vrijednosti. Tvrdnje prema suvremenim shvaćanjima pokazuju da danas, zbog različitih interdisciplinarnih pristupa toj temi, ne postoji univerzalno prihvaćena odrednica termina vrijednosti (Rakić i Vukušić, 2010, 773). Svaka znanost polazi od svojega posebnoga pogleda određivanja pojma, klasifikacije i hijerarhije vrijednosti. Bez obzira na poteškoće omeđivanja, jasno je da su vrijednosti poželjni društveni fenomeni, nužni za razvoj društva i razvoj osobe te da postoji kontinuitet prenošenja vrijednosti. U 21. stoljeću Rokeach (1973), ${ }^{14}$ Peterson i Seligman (2004) ${ }^{15}$ te Schwartz (2012) najčešce su citirani autori, koji su postali uzori u pokušajima klasifikacije i definiranja pojma vrijednosti. Shalom H. Schwarz tvorac je teorije zajedničkih ljudskih vrijednosti. Uporište za tu teoriju stvorio je na temelju istraživanja provedenoga na uzorku od preko osamdeset zemalja.

U kontekstu 21. stoljeća i činjenici da je Hrvatska danas dio Europske unije važno je istaknuti kako se zajednički europski identitet između ostaloga temelji na vrijednostima koje proizlaze iz Opće deklaracije o ljudskim pravima te su utemeljene na multikulturalnosti, interkulturalnosti i načelima demokracije, a sve u svrhu očuvanja temeljnoga preduvjeta opstanka Europske unije kao zajednice različitosti, a to je stabilnost i mir. Tako danas vrijednosti poput demokracije, tolerancije, solidarnosti, slobode, poštivanje ljudskih prava, poštivanje dostojanstva svakoga čovjeka, vladavine prava predstavljaju ne samo imperativ suživota u Europi, nego i zajednički sustav vrijednosti čitavoga ljudskoga roda. Međutim, ostaje otvoreno pitanje prihvaćaju li i u kojoj mjeri današnji mladi u Hrvatskoj navedene vrijednosti ili zbog pritiska suvremenoga načina života izgrađuju neki vlastiti sustav vrijednosti.

\section{Zaključak}

Danas postoje razlike u pristupu poimanja i definiranja pojma vrijednosti, ali prema općem prihvaćanju vrijednosti se smatraju rezultatima socijalizacije, pod utjecajem su individualnog iskustva te društvenih i kulturnih čimbenika (Ferić, 2007, 4-12). Nikako se ne može izbjeći činjenica da vrijednosti bitno utječu na stavove i ponašanja pojedinca (Rokeach, 1973, 345). Pored toga, važno je istaknuti i da su promjene duhovno-intelektualnih interesa i životnih potreba pojedinca utjecale na modificiranje sustava vrijednosti. Tako smo iz povijesti naučili

14 Milton Rokeach američki je socijalni psiholog čija je teorija dovela do niza mjerenja koja su vodila rezultatu da su usvojene vrijednosti dovele do mjerljivih promjena u ponašanju.

15 Oni su uz druge suradnike odlučili istražiti preko dvjesto različitih izvora, kao što su radovi Aristotela, Platona, Tome Akvinskoga, Augustina, Konfucija, Bude, Benjamina Franklina, Stari zavjet, Talmud, Bushido (samurajski kodeks) i sl. Proučavajući različite spise dali su povijesni pregled i klasifikaciju univerzalnih vrijednosti. 
da se sustav vrijednosti tijekom stoljeća mijenjao, ali i da su se određene vrijednosti nastavile ponavljati kao uvijek aktualne, od antike do danas.

U kontekstu razvoja suvremenoga društva, možemo reći kako vrijednosti treba tražiti na globalnoj razini. Stoga se može govoriti i o općeprihvaćenim ljudskim vrijednostima, koje nisu vezane za vrijeme i mjesto življenja (Piršl i Vican, 2004, 11-12), što upućuje na potrebu prenošenja trajnih vrijednosti u interakciji onih koji prebivaju zajedno, čineći skladan sustav zajedničkih ciljeva (Hooper, 2003, 170). Povijest je od antike do danas ostavila u nasljeđe primjere takvih vrijednosti koje su aktualne u svakom vremenu, a to su mudrost, odnosno razboritost, hrabrost, umjerenost, pravednost, požrtvovnost, skromnost, duhovnost, briga za roditelje i starije, ljubav prema domovini, dobrota, sloboda, pravda, mir, dostojanstvo, demokracija, jednakost, vladavina prava, ljudska prava, uključivost, tolerancija, solidarnost i nediskriminacija. ${ }^{16}$ Vrlo slični modificirani primjeri vrijednosti koje korespondiraju s univerzalnim vrijednostima mogu se danas pronaći u kurikulima pojedinih država, ali i u suvremenoj literaturi. Primjerice, u literaturi se ističu vrijednosti: sloboda, pravda, sreća, sigurnost, mir, ljubav, briga, poštovanje, odgovornost, tolerancija, iskrenost, poniznost, suradnja i solidarnost (Halstead i Taylor, 2010). Zatim, u Sažetku studije obrazovanja o vrijednostima u Australiji također se navode slične preporučene vrijednosti: sloboda, tolerancija, poštovanje, odgovornost, pravda, solidarnost, izvrsnost, iskrenost, etičnost (Hooper, 2003, 21-22). Slični primjeri koji korespondiraju s univerzalnim vrijednostima mogu se pronaći i u hrvatskom odgojno-obrazovnom sustavu. Tako se u temeljnom odgojno-obrazovnom dokumentu kao vrijednosti koje treba prenositi na mlade spominju: dostojanstvo ljudske osobe, sloboda, pravednost, domoljublje, društvena jednakost, solidarnost, dijalog i tolerancija, rad, poštenje, mir, zdravlje, očuvanje prirode i čovjekova okoliša te ostale demokratske vrijednosti (Ministarstvo znanosti i obrazovanja, 2017, 22). Iz svega navedenoga, sagledavajući vrijednosti u kontekstu odgoja i obrazovanja, možemo reći kako odgojnoobrazovne vrijednosti bilo kojega odgojno-obrazovnoga sustava korespondiraju s hijerarhijom univerzalnih vrijednosti (Mijatović, 2000, 284), koje vrijede od kada je čovjeka pa sve do danas.

\section{Literatura}

Aristotel (1982). Nikomahova etika. Zagreb: Politička misao.

Aristotel (1988). Politika. Zagreb: Globus.

Arthur, James (2020). The formation of character in education: from Aristotle to the 21st century. London: Routledge, Taylor \& Francis Group

Berčić, Boran (2008). Etika vrlina. Filozofska istraživanja, 28(1), 193-207.

Bognar, Ladislav; Svalina, Vesna (2013). Glazba i glazbeno obrazovanje u starom i srednjem vijeku. Napredak, 154(1-2), 219-233.

16 Autorice rada izdvojile su navedene vrijednosti iz prethodno napisanoga teksta s ciljem isticanja kontinuiteta prenošenja univerzalnih vrijednosti tijekom povijesti. Antičke vrijednosti danas imaju drukčije značenje: pokoravanje bogovima = duhovnost; požrtvovnost i pokoravanje roditeljima i starijima $=$ briga o roditeljima i starijima. 
Vjera Brković et al., Pregled razvoja odgoja i obrazovanja... Obnovljeni Život, 2021, 76(1), 113-124

Brčić, Marita (2006). Izvori liberalnog mišljenja u filozofiji Immanuela Kanta. Filozofska istraživanja, 26(4), 783-797.

CCE. Catechismus Catholicae Ecclesiae. Ivan Pavao II., Katekizam Katoličke crkve: Doradeno izdanje. Zagreb: Hrvatska biskupska konferencija, 2016.

Dewey, John (1953). Džon Djui: Vaspitanje i demokratija: Uvod u filosofiju vaspitanja. Cetinje: Obod.

Europska komisija (2016). Povelja Europske Unije o temeljnim pravima. Službeni list Europske unije, C 202/389. URL: https://eur-lex.europa.eu/legal-content/HR/TXT/ $\mathrm{PDF} /$ ?uri=CELEX:12016P/TXT\&from $=\mathrm{RO}(09.12 .2020$.

Europska unija (2007). Ugovor iz Lisabona. URL: http://www.mvep.hr/custompages/static/hrv/files/pregovori/111221-lisabonski-prociscena.pdf (09.12.2020.)

Ferić, Ivana (2007). Univerzalnost sadržaja i strukture vrijednosti: Podaci iz Hrvatske. Društvena istraživanja, 16(1-2), 3-26.

Golubović, Aleksandra (2013). Aktualnost Rousseauovih promišljanja filozofije odgoja s posebnim osvrtom na moralni odgoj. Acta Iadertina, 10, 25-36.

Grubiša, Damir (2010). Četiri orijentacije u političkoj misli europske renesanse. Politička misao, 47(2), 7-36.

Halstead, J. Mark; Taylor J. Monica (2010). Learning and Teaching about values: A review of recent research. Cambridge Journal od Education, 30(2), 169-202.

Hegel, Georg Wilhelm Friedrich (1976). Sustav ćudorednosti. Zagreb: Studentski centar Sveučilišta u Zagrebu.

Hobsbawm, Eric (1987). Doba revolucije: Evropa 1789-1848. Zagreb: Školska knjiga.

Hooper, Carol i dr. (ur.), (2003). Values education study: Literature review: Values education study: Final report. Melburn: Curriculum Corporation.

Kale, Eduard (1990). Povijest civilizacija. Zagreb: Školska knjiga.

Kokić, Tonći (2015). Pregled antičke filozofije. Zagreb: Naklada Breza.

Kovačević, Sonja; Mušanović, Luka (2013). Od transmisije do majeutike: Modeli nastave. Zagreb: Hrvatsko futurološko društvo.

Krasić, Stjepan (2012). Nastanak i razvoj školstva od antike do srednjega vijeka. Zadar: Sveučilište u Zadru.

La Mettrie, Julien Offray de (1955). Lametri: Čovek mašina. Beograd: Kultura.

Le Goff, Jacques (2011). Za jedan drugi srednji vijek: Vrijeme, rad i kultura na zapadu. Zagreb: Antibarbarus.

Legrand, Louis (1991). Enseigner la moral aujourd'hui? Paris: Universitaires de France.

Maslow, Abraham Harold (1968). Toward a Psychology of Being. London: D. Van Nostrand Company.

Mijatović, Antun (2000). Leksikon temeljnih pedagogijskih pojmova. Zagreb: Edip.

Ministarstvo znanosti i obrazovanja (2017). Okvir nacionalnoga kurikuluma: Prijedlog nakon javne rasprave. URL: https://mzo.gov.hr/UserDocsImages//dokumenti/Obrazovanje/NacionalniKurikulum/NacionalniKurikulumi//Okvir\%20nacionalnoga\%20 kurikuluma.pdf (22.04.2020.)

Mrnjaus, Kornelija (2007). Studenti i vrijednosti u Austriji i Hrvatskoj. Pedagogijska istraživanja, 4(1), 57-80.

Palekčić, Marko (2010). Herbartova teorija odgojne nastave — izvorna pedagogijska paradigma. Pedagogijska istraživanja, 7(2), 319-340.

Palmer, Richard E. (2007). The Gadamer reader: A Bouquet of the Later Writings. Illinois: Northwestern University Press. 
Obnovljeni Život, 2021, 76(1), 113-124 Vjera Brković et al., Pregled razvoja odgoja i obrazovanja...

Papo, Demian (2016). Vuk-Pavlovićevi stavovi o Lockeovu nauku. Metodički ogledi, 23(2), 29-41.

Peterson, Christopher; Seligman, Martin (2004). Character Strengths and Virtues: A Handbook and Classification. New York: Oxford University Press.

Piršl, Elvi; Vican, Dijana (2004). Europske demokratske vrijednosti i regionalizam. Pedagogijska istraživanja, 1(1), 89-103.

Pranjić, Marko (2013). Na iskonima europskoga odgoja: Telemah kao odgajanik. Zagreb: Matica hrvatska.

Rakić, Vini; Vukušić, Svjetlana (2010). Odgoj i obrazovanje za vrijednosti. Društvena istraživanja, 19(4-5), 771-795.

Ravlić, Slaven (2001). Politička ideologija: Preispitivanje pojma. Politička misao, 38(4), 146-160.

Rokeach, Milton (1973). The Nature of Human Values. New York: Free Press.

Schwartz, Shalom H. (2012). An Overview of the Schwartz Theory of Basic Values. Online Readings in Psychology and Culture, 2(1). URL: https://doi.org/10.9707/23070919.1116 (22.04.2020.)

Senković, Željko (2006). Aristotelov odgoj za vrline. Metodički ogledi, 13(2), 43-61.

Ujedinjeni narodi (2009). Opća deklaracija o ljudskim pravima. Narodne novine, br. 12. URL: https://narodne-novine.nn.hr/clanci/medunarodni/2009_11_12_143.html (09.12.2020.)

Ujedinjeni narodi (s. a.). Kovencija o pravima djeteta. Unicef.hr. URL: https://www.unicef.hr/wp-content/uploads/2017/05/Konvencija_20o_20pravima_20djeteta_full.pdf (09.12.2020.)

Veljak, Lino (2013). Je li prosvjetiteljstvo definitivno stvar prošlosti? Studia lexicographi$c a,(2), 119-127$.

Vergnioux, Alain (2017). Les Lumières et l'éducation. Paris: Hermann.

Vukasović, Ante (2013). Reafirmacija odgoja - alfa i omega pedagoškoga preporoda. Obnovljeni Život, 68(2), 253-262.

Zaninović, Mate (1988). Opća povijest pedagogije. Zagreb: Školska knjiga. 
Vjera Brković et al., Pregled razvoja odgoja i obrazovanja... Obnovljeni Život, 2021, 76(1), 113-124

An Overview of the Development of Values-Based Education in the Historical and Social Context

Vjera Brković*, Rona Bušljeta Kardum**

Summary

Values education is extremely important to the existence of the individual. Values have shaped the individual and society, and one may say that values education is an indispensable developmental social phenomenon regardless of historical changes. Given the importance of values education for the development of man and society, the aim of this paper is to identify the origins of universal educational values, reconstruct the historical and social background of the origins of values education and to highlight the continuities and changes in the development of values education. Briefly described in the paper is the fact that the value system has changed throughout history, but also that certain values have continued to be repeated, from antiquity to the present day. Some examples of universal educational values inherited in the course of history are: wisdom / prudence, courage, moderation, justice, sacrifice, modesty, spirituality, care for parents and the elderly, love of country, kindness, freedom, justice, peace, dignity, democracy, equality, rule of law, human rights, inclusiveness, tolerance, solidarity and non-discrimination.

Key words: axiology; education; historical and social context; universal values

* Vjera Brković, Lecturer, Ph.D. Candidate, Catholic University of Croatia, History Department. Address: Ilica 242, 10000 Zagreb, Croatia. E-mail: vjera.brkovic@unicath.hr

** Rona Bušljeta Kardum, Assistant Professor, Faculty of Croatian Studies, University of Zagreb. Address: Borongajska cesta 83d, 10000 Zagreb, Croatia. E-mail: rbusljeta@hrstud.hr 